\title{
The Relationship Between Stock Market Development And The Opacity Index
}

\author{
John Kamiru, Norfolk State University, USA
}

Carl B. McGowan, Jr., Norfolk State University, USA

\begin{abstract}
In this paper, we investigate the relationship between stock market development and the Opacity Index for 2005/2006, 2007/2008, and 2009. The role of financial institutions in promoting economic growth and development is well established. The specific role of the stock market in economic growth and development is to provide capital to entrepreneurs and growing companies and to direct capital to companies that provide the highest rate of return. The Opacity Index is a measure of transparency for an economy and measures the degree of transparency in an economy. We find a statistically significant relationship between the Opacity Index and the ratio of stock market capitalization divided by GDP for a sample of 45 countries for which the Opacity Index is provided.
\end{abstract}

Keywords: Stock Market Development; Economic Development; Transparency; Opacity Index

\section{INTRODUCTION}

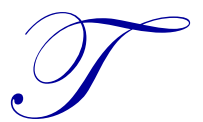

he role played by financial institutions and stock markets in promoting economic growth and development has been investigated extensively. The first bills of exchange were created in the twelfth century and the first stock market was created in Antwerp in the sixteenth century. McGowan (2008) argues that financial system development and economic growth and development leapfrog each other. As the economy becomes more complex, the need for more sophisticated financial institutions increases. Financial institutions reduce the cost of financial transactions making it possible for the economy to expand until such time as the need for financial transactions exceeds the ability of the financial system to accommodate all the necessary transactions. At this point, financial system innovation is necessary to allow the economy to grow. Thus, Demetriades and Hussein (1996) find that causality between financial system development and economic growth and development does not flow in one direction but may be bi-directional or flows in both directions. At any point in time, either financial system development or economic growth and development may precede or lag.

Diamond (1997), Maddison (2001), and Bernstein $(2002,2004)$ investigate the role of financial institutions over long periods of time and find a positive relationship between financial institutions and economic growth and development. Diamond views economic development for the past 13,000 years and finds that agricultural surpluses allowed societies to expand and develop and that greater surpluses were created in societies in locations with more domesticable species of plants and animals. Maddison explores the two thousand years up to the middle of the nineteenth century (1820) and the industrial revolution. One of the factors that Maddison posits is the development of financial institution innovations, such as stock markets. Bernstein explores the period after 1820 and posits that modern capital markets are a factor in the rapid economic growth and development over the last two hundred years. Capital markets provide deficit economic units with the financial resources to support the rapid growth over this period.

Rajan and Zingales (1998), Levin and Zervos (1998), King and Levine (1993), Beck, Levine, and Loayza (2000) find a positive relationship between financial development and economic growth and development. Rajan and Zingales analyze the relationship between external financing and relative capital spending in industries in fortyone countries between 1980 and 1990. The authors conclude that developed financial credit markets provide funding to allow industries to expand. Levine and Zervos analyze the relationship between stock market 
development and bank credit and economic growth and development in forty-seven countries for the period 19761993. Developed stock markets improve resource allocation which, in turn, encourages economic growth and development. King and Levine find that economic growth and development and financial system development were positively related from 1960 to 1989 . Beck, Levine, and Loayza find a positive relationship between financial development and the growth of real GDP per capita because of increases in total factor productivity. Atje and Jovanovic (1993) find a positive relationship between stock market development and economic development for forty countries between 1960 and 1985. Wurgler (2000) finds a positive relationship between stock market development and economic development because stock markets reallocate resources from declining to growing industries.

The initial research on growth accounting was developed by Abramovitz (1956) and Solow (1975). As observed by Young (1995), the growth accounting procedure assumes that input $i$ today is the same as it was yesterday. Hence, according to Young (1995), the procedure places any increase in the productivity of that input into the residual. We expand this theory by arguing that growth accounting can be used to explain the stock market growth and development. To this end, we hold to the view, as expressed by Levine and Zervos (1998), that the stock market has a positive relationship to economic growth and that there is a strong link between financial development and economic growth. Further, Yartey (2008) shows that stock market development is expected to accelerate economic growth through increased domestic savings and investment spending.

We further postulate that the macroeconomic determinants of stock market development tend to vary from country to country. The highly developed economies have institutional characteristics that are well developed. However, in emerging and developing economies, the level of institutional development is lower and stock market performance will reflect these differences. Further, differences in stock market development exist among developing countries. As observed by Naceur, Ghazouani, et al. (2007), the level of stock market development in the Middle East and North African (MENA) countries varies within this subgroup. In such cases, variations are to be expected due to economic endowment and political differences among countries. The highly endowed countries with stable political systems have a higher level of economic development and well developed stock markets. This view is supported by Cherif and Gazdar (2010) in their study of MENA countries.

\section{RESEARCH DESIGN}

We test the relationship between the Opacity Index and the ratio of stock market capitalization to GDP ratio. The Opacity Index is for 2005/2006, 2007/2008, and 2009 and the stock market capitalization to GDP ratio is for 2006, 2008, and 2009. The Opacity Index is derived from the CLEAR model where Kurtzman and Yago (2007) discuss a model to examine transparency developed at the Milken Institute. The Opacity Index is an equally weighted average of five variables that measure transparency in a country. The database provides the Opacity Index for forty-eight countries of which forty-five have stock market data. The five variables used to construct the Opacity Index measure the level of corruption, the effectiveness of the legal systems, the effectiveness of enforcement policies, the transparency of accounting, and regulatory quality and enforcement (Kurtzman and Yago, 2007, pp. xiii-xiv). The Opacity Index is an equally weighted index of the five factors. Corruption is measured by the frequency of demands for illicit activity (Kurtzman and Yago, 2007, pp. 72). Legal system complexity is an equally weighted index of the procedural complexity index and the employment laws index (Kurtzman and Yago, 2007, pp. 87). Accounting opacity is measured by auditing spending, insider trading laws, and shareholder protection (Kurtzman and Yago, 2007, pp. 112-113). Regulatory opacity is measured by twenty-four measures of the regulatory environment (Kurtzman and Yago, 2007, pp. 132).

The dependent variable used in this study is the ratio of stock market capitalization divided by gross national income (GDP) taken from the World Development Indicators 08.

$\mathrm{MCGDP}=\mathrm{MC} / \mathrm{GDP}$

where MCGDP is the total stock market capitalization to gross domestic product and is equal to total stock market capitalization divided by gross domestic product. 
We regress the Opacity Index, OI, as the independent variable, against MCGDP, as the dependent variable.

$\operatorname{MCGDP}=\alpha+\beta(\mathrm{OI})+\varepsilon$

where MCGDP is the dependent variable and measures the extent of stock market integration into the financial system, $\alpha$ is the intercept term, $\beta$ is the regression coefficient for the independent variable, OI, and, $\varepsilon$ is the residual which is the variability in MCGDP not explained by the independent variable.

\section{EMPIRICAL RESULTS}

Figures 1 and 2, as well as Figure 3, show the graphical relationship between the MCGDP and OI for the forty-five countries in the sample. Three countries are eliminated from the sample because of incomplete data. The relationship is linear and downward sloping. The negative slope results because the Opacity Index is low for countries that are more transparent and high for countries that are less transparent. Thus, a high Opacity Index indicates that the country in question has low transparency, while a low Opacity Index indicates that the country in question has high transparency. High transparency indicates low opacity and low transparency indicates high opacity.
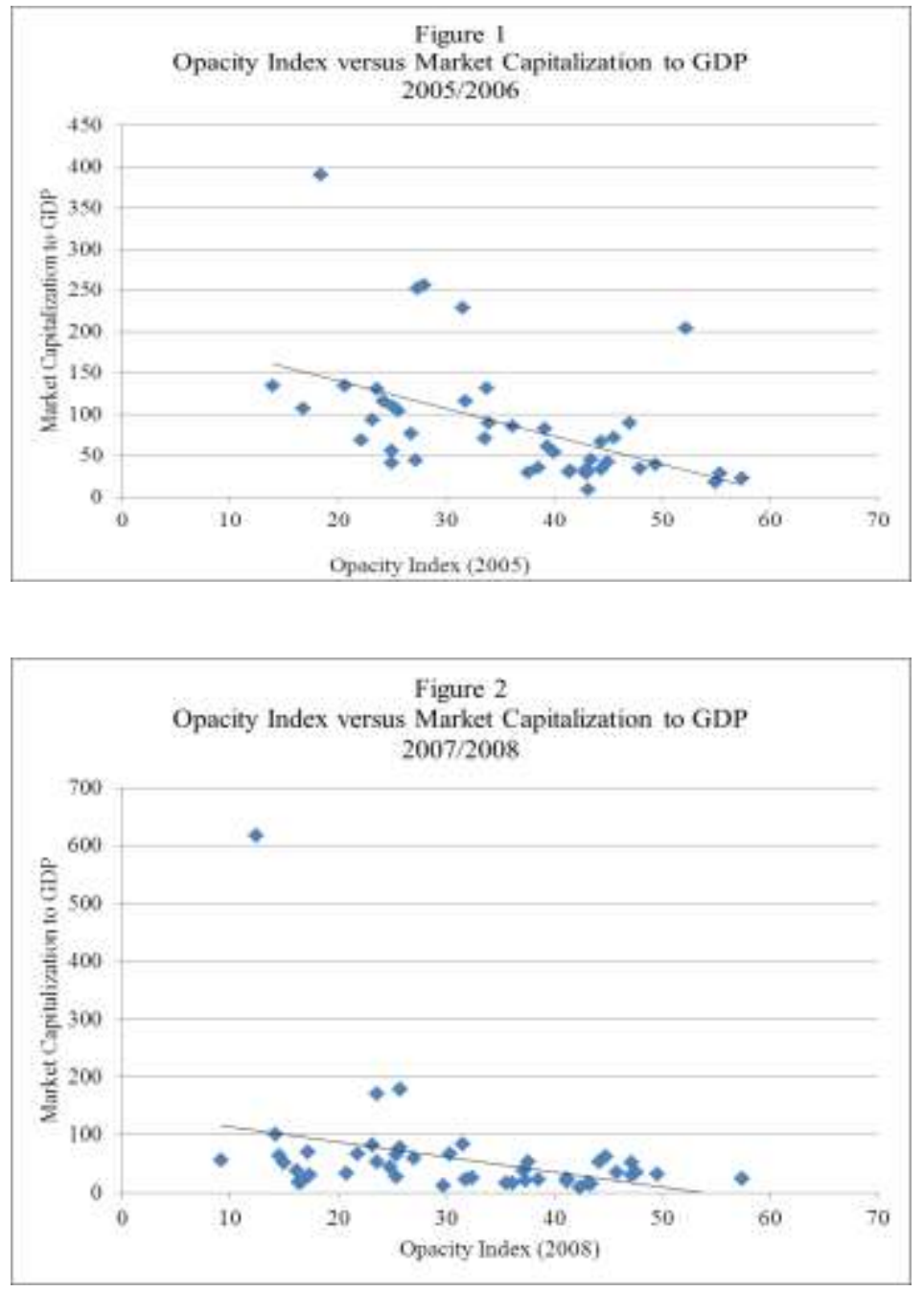


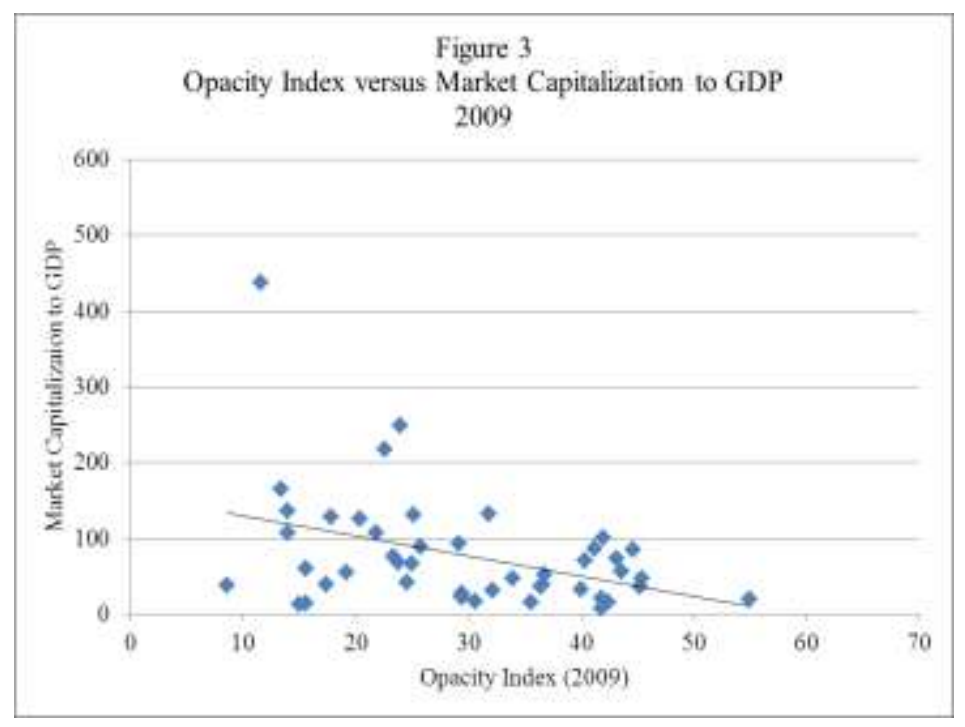

Table 1 provides the results for the three regressions between the Opacity Index and the MCGDP for the three sample periods. The adjusted $\mathrm{R}^{2}$, s are $0.2272,0.0971$, and 0.1399 for the three regressions and the $\mathrm{F}$-ratios are 12.93, 5.73, and 8.16, which indicate that all three regressions are statistically significant at the 5\% level. The intercept terms are 208, 140, and 156 and are statistically significant at the 5\% level. The regression coefficients for the independent variable, Opacity Index, are $-3.37,-2.60$, and -2.65 and are statistically significant at the five percent level. These empirical results indicate that there is an inverse relationship between opacity and stock market integration. That is, the higher the Opacity Index, the lower is stock market development. Alternatively, high transparency is related to higher stock market development.

When major outliers are removed, the relationship increases in statistical significance.

Table 1: Opacity versus Market Capitalization to GDP (2005 to 2009)

\begin{tabular}{|l|c|c|c|}
\hline \multicolumn{1}{|c|}{ Statistic } & Year 2005/06 & Year 2007/08 & Year 2009 \\
\hline Intercept & 209 & 141 & 157 \\
\hline T Statistic & 6.16 & 3.90 & 5.34 \\
\hline Coefficients & -3.37 & -2.60 & -2.65 \\
\hline T Statistic & -3.73 & -2.39 & -2.86 \\
\hline F Ratio & 13.94 & 5.73 & 8.16 \\
\hline Adjusted R Square & 0.2272 & 0.0971 & 0.1399 \\
\hline Number of Observations & 45 & 45 & 45 \\
\hline
\end{tabular}

\section{SUMMARY AND CONCLUSIONS}

In this paper, we analyze the relationship between transparency, measured by the Opacity Index, and stock market integration, measured by the ratio of stock market capitalization and gross domestic product. Economic growth and development are related to capital market development. High income economies have developed capital markets. Countries that wish to promote economic growth and development should create economic environments that allow more choice to both domestic companies and foreign companies. Stoever (2002a) provides a framework to describe the relationship between the economic environment and economic growth and development. A liberalized economic environment promotes economic growth and development by providing more choices to multinational companies seeking foreign direct investment opportunities. Multinational companies are more likely to choose to invest in countries in which more choices are available, that is, where restrictions on choices are fewer. Companies invest more in countries where the economic environment allows more freedom of choice. Lower risk leads to lower required rate of return on the part of the multinational company, leading to greater surplus remaining within the host country. Stoever (2002b) develops a measure of political openness for Korea and shows the positive 
impact of liberalization on foreign direct investment. Bekaert, Harvey, and Lundblad (2001) show that countries that wish to create more investment-friendly economic environments must liberalize the economic environment. Liberalization leads to increased stock market integration which promotes economic growth and development. Bekaert, Harvey, and Lumsdaine (2002) show that liberalization of financial markets in developing economies leads to greater economic growth and development. However, liberalization dates are not those on which regulations are created, but dates when regulatory changes actually become effective, which is usually after the official enactment date.

Our empirical results confirm the relationship between transparency, measured by the Opacity Index, and stock market integration in the economy, measured by stock market capitalization to GDP, which promotes economic growth and development for three different time periods. Countries that have greater transparency in institutions, as measured by a lower Opacity Index, have greater stock market integration and, thus, greater access to capital for investing companies which leads to higher rates of economic growth and development. The more transparent the economic regulatory environment in a country, the greater stock market integration and the greater economic growth and development.

\section{AUTHOR INFORMATION}

Dr. John Kamiru earned his Ph.D. in Economics in 2005 from Howard University, Washington, DC, USA. He is currently Assistant Professor of Economics and Coordinator of Faculty and Students Research Series at the School of Business, Norfolk State University, Virginia, USA. E-mail: JKamiru@nsu.edu

Carl B. McGowan, Jr., PhD, CFA is a Faculty Distinguished Professor and Professor of Finance at Norfolk State University, has a BA in International Relations (Syracuse), an MBA in Finance (Eastern Michigan), and a PhD in Business Administration (Finance) from Michigan State. From 2003 to 2004, he held the RHB Bank Distinguished Chair in Finance at the Universiti Kebangsaan Malaysia and has taught in Cost Rica, Malaysia, Moscow, Saudi Arabia, and The UAE. Professor McGowan's research is in the areas of corporate and international finance. Professor McGowan has published 81 peer reviewed articles and 94 proceedings and has presented 188 papers at regional, national, and international conferences. He has published in American Journal of Business Education, Applied Financial Economics, Decision Science, Financial Practice and Education, The Financial Review, International Business and Economics Research Journal, The International Review of Financial Analysis, The Journal of Applied Business Research, The Journal of Business Case Studies, The Journal of Diversity Management, The Journal of Real Estate Research, Managerial Finance, Managing Global Transitions, The Southwestern Economic Review, and Urban Studies. E-mail: cbmcgowan@yahoo.com (Corresponding author)

\section{REFERENCES}

1. Abramovitz, Moses. "Resource and Output Trends in the United States Since 1870," American Economic Review 46, May: 5-23.

2. Atje, Raymond and Boyan Jovanovic. "Stock Markets and Development," European Economic Review, volume 37, 1993, pp. 632-640.

3. Bakaert, Geert, Campbell R. Harvey, and Robin L. Lumsdaine. "Dating the Integration of World Equity Markets," Journal of Financial Economics, volume 65, 2002, pp. 203-247.

4. Beck, Thorsten, Ross Levine and Norman Loayza. "Finance and the Sources of Growth," Journal of Financial Economics, volume 58, 2000, pp. 261-300.

5. Bernstein, William J., The Birth of Plenty, McGraw-Hill, New York, 2004.

6. Bernstein, William J. "Of Markets, Economies, and Populations," Efficient Frontier, Summer 2002.

7. Cherif, Mondher and Gazdar, Kaouthar. "Institutional and Macroeconomic Determinants of Stock Market Development in MENA Region: New Results from a Panel Data Analysis," International Journal of Banking and Finance: Vol. 7: Iss. 1, 2010, Article 8, pp. 139-159.

8. Demetriades, Panicos O. and Khaled A. Hussein. "Does Financial Development Cause Economic Growth? Time-series Evidence from 16 Countries," Journal of Development Economics, volume 51, 1996, pp. 387411.

9. Diamond, Jared. Guns, Germs, and Steel: The Fates of Human Societies, Random House, 1997. 
10. King, Robert G. and Ross Levine. "Finance and Growth: Schumpeter Might Be Right," Quarterly Journal of Economics, volume 108, August 1993, pp. 717-737.

11. Kurtzman, Joel and Glenn Yago, Global Edge - Using the Opacity Index to Manage the Risks of CrossBorder Business, Harvard Business School Press, Boston, 2007.

12. Levine, Ross and Sara Zervos. "Stock Markets, Banks, and Economic Growth," American Economic Review, volume 88, number 3, 1998, pp. 537-558.

13. Maddison, Angus. The World Economy: A Millennial Perspective, Development Centre of the Organization for Economic Co-Operation and Development, 2001.

14. McGowan, Carl B., Jr. "An Illustration of the Impact of Economic and Political Risk Using the Country Credit Rating Model," Managing Global Transitions: International Research Journal, Volume 6, Number 2, Summer 2008, pp. 143-156.

15. Naceur, Ben Samy, Ghazouani, Samir and Omran, Mohamed, "The Determinants of Stock Market development in the Middle-Eastern and North African Region," Managerial Finance, Vol.33 No.7 2007, pp. 477-489.

16. Nourrzad, Farrokh. "Financial Development and Productive Efficiency: A Panel Study of Developed and Developing Countries," Journal of Economics and Finance, volume 26, number 2, Summer 2002, pp. 138149.

17. Rajan, Raghuram G. and Luigi Zingales. "Financial Dependence and Growth," American Economic Review, volume 88, number 3, pp. 559-586.

18. Solow, Robert M. "Technical Changes and the Aggregate Production Function," Review of Economics and Statistics 39, 1957, pp. 312-320.

19. Stoever, William. "Restructuring FDI Policy in Developing and Transition Economies: Frameworks for Analysis: With and Application in Korea," Proceedings of the 2002 Academy of International Business Northeast Conference, Salisbury, MD, (2002): 43-55.

20. Stoever, William. "Attempting to Resolve the Attraction-Aversion Dilemma: A Study of FDI Policy in the Republic of Korea," Transnational Corporations, 11, 1, (2002): 49-76.

21. World Development Indicators 08, The International Bank for Reconstruction and Development, The World Bank, 2008, pp. 280-282.

22. Wurgler, Jeffrey. 'Financial Markets and the Allocation of Capital," Journal of Financial Economics, volume 58, 2000, pp. 187-214.

23. Young, Alwyn. "The Tyranny of Numbers: Confronting the Statistical Realities of the East Asian Growth Experience," The Quarterly Journal of Economics, Vol. 110, No. 3(Aug., 1995), pp.641-680. 